\title{
Parvovirus B19: Evaluation of Incidence, Prevalence and Risk Factors among Pregnant Women Attending Ante-Natal Clinic in Nasarawa State, North Central of Nigeria
}

\author{
Akyala Ishaku. A ${ }^{1, *}$, Amuta E. $\mathbf{U}^{2}$, A zua A. T², Agie ni As he m Godwin ${ }^{3}$ \\ ${ }^{1}$ Department of science laboratory technology, Nasarawa State Polytechnic,Lafia \\ ${ }^{2}$ Biological science Department, University of Agriculture, Makurdi, Benue State \\ ${ }^{3}$ Dept of Microbiology, Kogi State University, Anyigba
}

\begin{abstract}
Trans-placentaltransmission of parvovirus B19 during pregnancy has been reported as one of the leading causes of non-immune fetal hydrops, spontaneous abortion or intra-uterine fetal death. We therefore set out to determine the presence of parvovirus B19 (Ig G and $\operatorname{IgM}$ ) antibodies and their risk factors among pregnant wo men attending ante-natal clin ic, at Federal Medical Center, Keffi, Nasarawa State, Nigeria.A total of 273 pregnant women (Age range 15-40 years) participated after informed consent and clearance from the research ethics committee. Each filled a self-administered questionnaire and donated blood samples between January and August 2012. A recombinant parvovirus B19 IgM and Ig G ELISA kit from DeMediTec (USA) was used for the assays.Of the 273 participants, 36 (13.2\%) had IgM antibodies, while 75 (27.5\%) had Ig Gantibodies with those aged 15-20 and 36-40 years having the highest incidence and prevalence rates. Being a house wife, having more children and histories of blood transfusion, miscarriage and still birth were associated with infection $(\mathrm{P}<0.05)$. The study reveals high incidence and prevalence of parvovirus $\mathrm{B} 19$ infection among the pregnant women. The presence of parvovirus B19 IgM antibody particularly in the first and second trimesters of pregnancy poses the danger of likely trans placental transmission leading to spontaneous abortion and intra-uterine fetal death.
\end{abstract}

Keywords Parvo B19, Pregnant, Risk, Nasarawa State, Trans-placental

\section{Introduction}

Human parvovirus B19 is the only known parvovirus pathogenic to human[1,2]. The infection during pregnancy may account for thousands of incidences of fetal loss per annum in Europe, North A merica and beyond[3].

Trans-placental transmission of parvovirus B19 during pregnancy is one of the leading causes of non-immune fetal hydrops, spontaneous abortion or intra uterine fetal death $[4,5]$. The disease which was first discovered in 1975[6] was first associated with disease in 1981, when it was linked to aplastic crisis, fifth disease, spontaneous abortion and some form of acute arthritis[7]. It also has a 33\% vertical transmission rate with a 2-3 incidences in all spontaneous abortion[8].

B19 may also stimulate a cellular process initiating apoptosis[9]. This may account for the minimal

* Corresponding author:

akyalaisaac@yahoo.com (Akyala Ishaku. A)

Published online at http://journal.sapub.org/cmd

Copyright (C) 2012 Scientific \& Academic Publishing. All Rights Reserved inflammatory response noted in tissues infected with $B 19[10]$.The virus infection of megakaryocytes, placental cells, fetal liver cells and myocardial cells results in anemia, which can lead to high output congestive heart failure, causing fetal circulatory compromise. The risk of fetal demise is highest in the first trimester and is thought to be as high as $10 \%$ in wo men who are infected prior to 20 weeks of gestation[11]. The $\mathrm{P}$ blood group antigen, which serves as a receptor for B19, has been detected on cells of the villous trophoblast of placental tissues in varying amount during the course of pregnancy. And in the first trimester of pregnancy, the level of the P-antigen is very high. This high level of globoside receptor on placental cells in early pregnancy may act as a pathway for B19 to be transmitted fro m the mother to the fetus where by the virus can then infect erythroid progenitor cells for replication[12]. There are limited data on the incidence and prevalence of parvovirus B19 in Nigeria in spite of the importance of such data in health policy formulation. We therefore, undertook a survey to establish the incidence, prevalence and risk factors of this agent among pregnant women attending Plateau specialist hospital in Jos. 


\section{Materials and Methods}

\subsection{Study Area}

The study was conducted in Nasarawa State. Nasarawa State is located in the north central geopolitical zone of Nigeria. It lies between latitude $80^{\circ} 35^{\prime} \mathrm{N}$ and longitude $08^{0} 36^{\prime}$ E. It is bounded to the North West by Federal capital territory (FCT), Abuja, and to the North-east by Plateau state, to the southeast by Taraba and to the north by Kaduna State, to the south by Benue State and to the southwest by Kogi State. It has a land mass of 21, 117 square kilo metres with a population of $2,100,000$, making it the $10^{\text {th }}$ largest state in Nigeria (2006 census).

It enjoys a more temperate climate than the rest of Nigeria and has an average monthly temperature range from $70^{\circ}$ to $77^{\circ} \mathrm{F}$ or $21^{\circ}$ to $25^{\circ} \mathrm{C}[13]$

\subsection{Study Population}

This consisted of pregnant women attending ante-natal clin ic in Federal Medical Center, Keffi, between January and August, 2012. The hospital has an average of 70 pregnant wo men attending ante-natal clinic weekly and population of two hundred and seventy three (273) subjects participated in this study.

\subsection{Ethical Consider ations}

Clearance from the health research ethical committee of Federal Medical Center, Keffi was obtained in accordance with the code of ethics for biomedical research involving human subjects. Signed informed consent was also obtained from each of the subjects.

\subsection{Exclusion and Inclusion Criteria}

The study inclusion criteria were being pregnant, ante-natal clinic attendance records and signed informed consent; while the exclusion criteria included absence of pregnancy, age below 15 and above 40years and failu re to sign a consent form.

\subsection{Specimen Collection}

After collection of the signed informed consent form, and the self-administered questionnaires with the relevant personal information, $5 \mathrm{mls}$ of blood sample from each subject was aseptically collected by venipuncture of the cubital vein using disposable needles and syringes. The samples were collected between January and August, 2012, and then taken to Innovative Biotech Virology Laboratory where the sera were separated, put into sample vials and stored at $-20^{\circ} \mathrm{c}$ until as sayed.

\subsection{Ass aying Technique}

The DeMeditec parvovirus B19 IgM and IgG (Recombinant) En zyme immunoassay kit[Lot; 123G/K038] USA was used for the in-vitro qualitative and semi-quantitative determination of immunoglobulin class antibodies assay for parvovirus B19 in serum, according to the manufacturer's instructions.

\subsection{Inter pretation of Results}

Incidence was defined as the presence of $\operatorname{IgM}$ antibodies to parvovirus B19 in the tested subjects, while prevalence was defined as the presence of parvovirus B19 $\mathrm{IgG}$ antibodies. The presences of $\operatorname{IgM}$ or $\operatorname{IgG}$ antibodies were determined by comparing the absorbance value of each sample to that of the cut-off value. Specimens with absorbance values less than the cut-off values were recorded as negative while those above are recorded as positive according to the manufacturer's instructions.

\subsection{Statistical Analysis}

Pearson chi-squares were calculated and compared with values on a chi-square table at $95 \%$ confidence interval. $\mathrm{P}$ values $\leq 0.05$ were considered statistically significant.

\section{Results}

Blood samples we re collected from 273 pregnant women. The serum samples were analyzed for parvovirus B19 (IgM and $\mathrm{IgG}$ ) antibodies. Of the 273 samp les assayed, 36(13.2\%) were positive for Parvovirus B19 IgM and 75(27.5\%) for B19 Ig G.

Figure 1 shows the distribution of parvovirus B19 antibodies according to age. The highest IgM antibodies (16.7\%) and $\operatorname{IgG}$ antibodies (37.5\%) antibodies were observed in the age groups $15-20$ and $36-40$ years respectively, while the lowest Parvovirus B19 $\operatorname{IgM}$ antibodies and $\operatorname{IgG}$ antibodies were observed in the age group 36-40 and 15-20 years respectively $(\mathrm{P}>0.05)$.

Table 1 shows the distribution of parvovirus B19 antibodies according to gestational age. The highest IgM antibodies (13.3\%) and $\operatorname{IgG}$ antibodies (31.1\%) were observed among pregnant women in their second trimester, followed by those in their first trimester. Those in their third trimester gave the least prevalence (For IgM, $\mathrm{P}>0.05$ while for $\operatorname{Ig} \mathrm{G}, \mathrm{P}=0.05)$.

Table 2 shows the distribution of parvovirus B19 antibodies according to history of pregnancy complications (miscarriage and stillbirth). The highest IgM antibodies $(20.0 \%)$ and $\operatorname{Ig} \mathrm{G}$ antibodies (40.0\%) were observed among those who have had his tory of both miscarriage and still birth. The lowest IgM antibodies (10.5\%) and IgG antibodies (22.8\%) were observed among pregnant women with no history of pregnancy complications $(\mathrm{P}>0.05)$.

Table 2 shows the distribution of parvovirus B19 antibodies according to the number of children in the household. The highest IgM antibodies (19.5\%) and Ig G antibodies $(42.9 \%)$ were observed among those with 5 or more children. The lowest IgM antibodies (10.6\%) and IgG antibodies (19.2\%) were observed among those with 0-2 children (For IgM, $\mathrm{P}>0.05$, while for $\operatorname{Ig} \mathrm{G}, \mathrm{P}<0.05$ ). 
Table 2 shows the distribution of B19 antibodies according to history of blood transfusion. The highest IgM antibodies (23.1\%) and $\operatorname{Ig} G$ antibodies $(30.8 \%)$ were observed among those who has been trans fused with blood at one occasion or another, while the lowest IgM antibodies $(26.9 \%)$ and $\operatorname{Ig} \mathrm{G}$ antibodies $(11.5 \%)$ respectively were found among those who have not received blood transfusion (For $\operatorname{IgM}, \mathrm{P}<0.05$, while for $\operatorname{Ig} \mathrm{G}, \mathrm{P}>0.05$ ).
Table 2 shows the distribution of parvovirus B19 antibodies according to occupation of the subjects. The highest IgM antibodies (26.7\%) and Ig G antibodies (40.0\%) were observed among pregnant women who are housewives. The lowest $\operatorname{IgM}$ antibodies (7.4\%) and $\operatorname{IgG}$ antibodies (24.4\%) were observed among those who are civil servants and business wo men respectively (For $\operatorname{IgM}, \mathrm{P}<0.05$, while for Ig G, P $>0.05$ ).

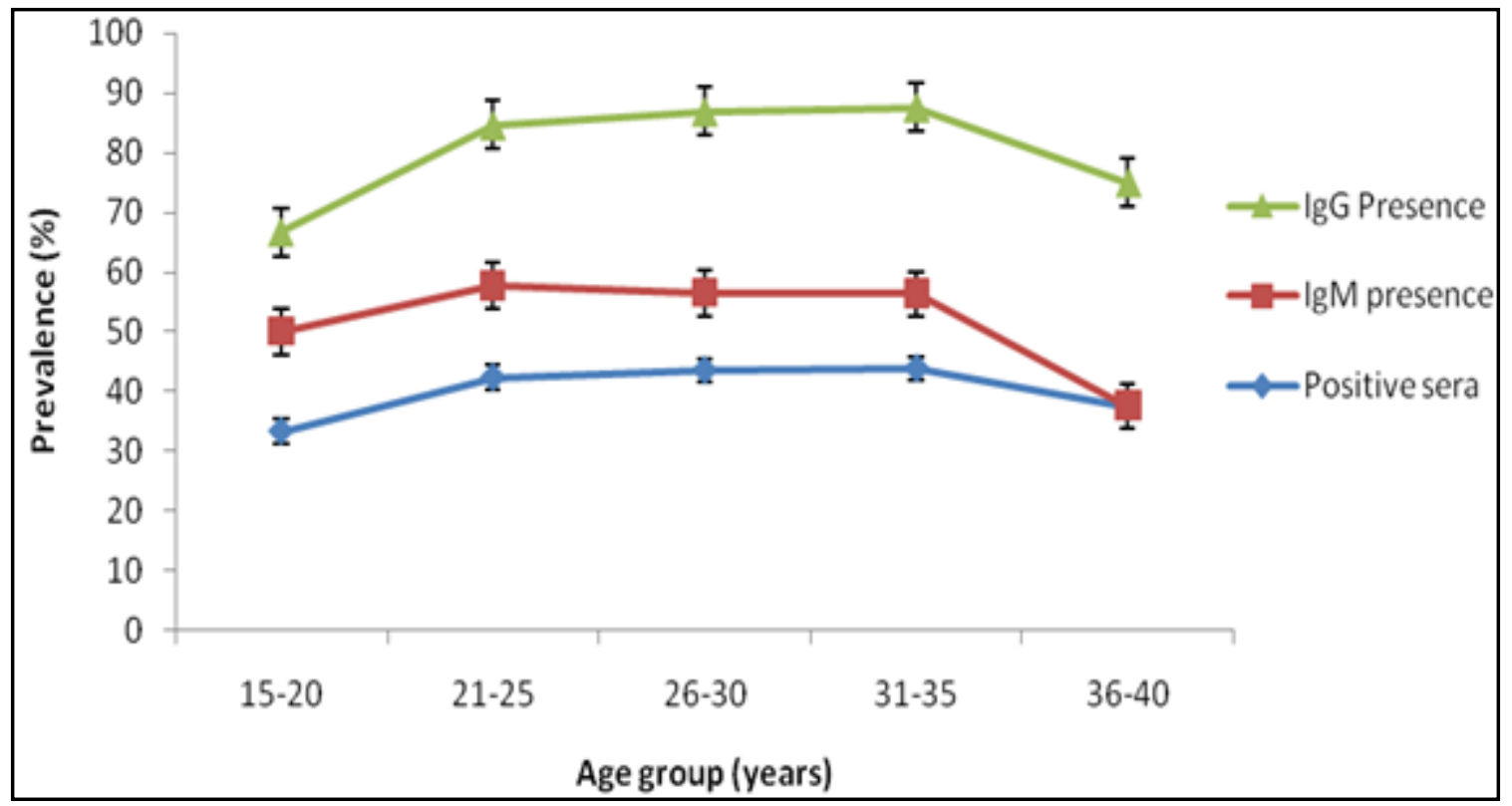

Figure 1. Prevalence of Parvo B19 antibodies among pregnant women in nasarawa Stata, Nigeria

Table 1. Distribution of Parvovirus B19 IgM antibodies by Risk Factors Among Pregnant Women Attending Ante-natal in Nasarawa State, Nigeria

\begin{tabular}{|c|c|c|c|c|}
\hline Risk factor Value & No Tested & No Positive (\%) & $\mathrm{X}^{2}$ & $\mathbf{P}$ \\
\hline \multicolumn{5}{|l|}{ Gestational Age } \\
\hline First Trimester & 114 & $15(13.2 \%)$ & & \\
\hline Second Trimester & 135 & $18(13.3 \%)$ & 0.03 & $>0.05$ \\
\hline Third Trimester & 24 & $3(12.5 \%)$ & & \\
\hline \multicolumn{5}{|c|}{ His tory of Complication } \\
\hline Miscarriage & 54 & $9(16.7 \%)$ & & \\
\hline Still Birth & 33 & $6(18.2 \%)$ & 5.93 & $>0.05$ \\
\hline Both & 15 & $3(20.0 \%)$ & & \\
\hline None & 171 & $18(10.5 \%)$ & & \\
\hline \multicolumn{5}{|c|}{ No of Children in Household } \\
\hline $0-2$ & 141 & $15(10.6 \%)$ & & \\
\hline $3-4$ & 69 & $9(13.0 \%)$ & 5.02 & $>0.05$ \\
\hline 5 or more & 63 & $12(19.0 \%)$ & & \\
\hline \multicolumn{5}{|c|}{ History of Blood Transfusion } \\
\hline Yes & 39 & $9(23.1 \%)$ & 5.57 & $<0.05$ \\
\hline No & 234 & $27(11.5 \%)$ & & \\
\hline \multicolumn{5}{|l|}{ Occupation } \\
\hline Students & 12 & $3(25.0 \%)$ & & \\
\hline Business & 135 & $15(11.1 \%)$ & & \\
\hline Civil Servants & 81 & $6(07.4 \%)$ & 19.99 & $<0.05$ \\
\hline House wife & 45 & $12(26.7 \%)$ & & \\
\hline
\end{tabular}


Table 2. Distribution of Parvovirus B19 IgG antibodies by Risk Factors Among Pregnant Women Attending Ante-natal Nasarawa State, Nigeria

\begin{tabular}{|c|c|c|c|c|}
\hline Risk factor Value & No Tested & No Positive (\%) & $\mathrm{X}^{2}$ & $\mathbf{P}$ \\
\hline \multicolumn{5}{|l|}{ Gestational Age } \\
\hline First Trimester & 114 & $30(26.3 \%)$ & & \\
\hline Second Trimester & 135 & $42(31.1 \%)$ & 5.99 & $=0.05$ \\
\hline Third Trimester & 24 & $3(12.5 \%)$ & & \\
\hline \multicolumn{5}{|c|}{ His tory of Complication } \\
\hline Miscarriage & 54 & $21(38.9 \%)$ & & \\
\hline Still Birth & 33 & $9(27.3 \%)$ & 4.89 & $>0.05$ \\
\hline Both & 15 & $6(40.0 \%)$ & & \\
\hline None & 171 & $39(22.8 \%)$ & & \\
\hline \multicolumn{5}{|c|}{$\begin{array}{l}\text { No of Children in Household } \\
\end{array}$} \\
\hline $0-2$ & 141 & $27(19.1 \%)$ & & \\
\hline $3-4$ & 69 & $21(30.4 \%)$ & 10.65 & $<0.05$ \\
\hline 5 or more & 63 & $27(42.9 \%)$ & & \\
\hline \multicolumn{5}{|c|}{ His tory of Blood Transfusion } \\
\hline Yes & 39 & $12(30.8 \%)$ & 0.2 & $>0.05$ \\
\hline No & 234 & $63(26.9 \%)$ & & \\
\hline \multicolumn{5}{|l|}{ Occupation } \\
\hline Students & 12 & $3(25.0 \%)$ & & \\
\hline Business & 135 & $33(24.4 \%)$ & & \\
\hline Civil Servants & 81 & $21(25.9 \%)$ & 3.86 & $>0.05$ \\
\hline House wife & 45 & $18(40.0 \%)$ & & \\
\hline
\end{tabular}

\section{Discussion}

This study identifies an incidence $(13.2 \%)$ and prevalence $(27.5 \%)$ of parvovirus $\mathrm{B} 19$ at three tertiary health care institution in Nasarawa State,which has an average of 70 pregnant women attending ante-natal clinic weekly. The incidence of $13.2 \%$ and prevalence of $27.5 \%$ agrees closely with the reports of Keikha et al in Iran who reported 10.3\% incidence and $21.8 \%$ prevalence in pregnancy[14]. It also accords with the 30-50\% range reported in India by Kaur and Basu, and also with 30-60\% prevalence range reported in United States by the American Academy of Pediatrics Committee on infectious Diseases,[1,15]. Our finding is however, lower than the $63-71 \%$ prevalence range reported in Dublin, Ireland, by Eis-Hubinger, and the $70 \%$ reported in United Kingdom and Finland among adults by Masssong et al $[16,17]$. It is however very high compare to the $2.0 \%$ incidence among blood donors in North Africa (Tunisian) and Western Europe (Belgian) reported by Letalef et al[18]. There is no clear explanation for this difference.

The incidence of parvovirus according to age groups was observed to decrease simultaneously with increase in ages while the prevalence was found to increase with increase in age groupings. This trend could be due to chances of exposure to the infection with age. A report of increase seroprevalence with age and greater than $70 \%$ in adult's populations was reported by Kerr et al,[19].

The outcome of the highest incidence (13.3\%) and prevalence $(31.1 \%)$ in the second trimester in the gestational age of pregnancy could probably be explained as susceptibility due to hormonal changes with progress in pregnancy. Since the presence of $\operatorname{IgM}$ antibodies signifies recent infection, it therefore poses the danger of transplacental transmission with the risk of fetal anae mia and demise highest in the first and second trimester especially for women infected prior to 20 weeks of gestation. A similar report was made by Markenson, and Enders et al[11,24].

The observation from the history of pregnancy complications, in which those with both miscarriage and still birth experience a higher parvovirus B19 incidence and prevalence when compared with those with no such history, further emphasizes the possible outcome of the effect of parvovirus B19 infection during pregnancy.

The outcome of the incidence and prevalence of parvovirus B19 antibodies among those with more number of children as against those with few or no children, suggests the involvement of contact with more number of children as a possible source of spread of the infection. However, previous reports identified children are the main sources of transmission, and outbreaks can pers ist for months in schools and day care centers, due to the relatively large number of seronegative children and close contact of children within this environment,[20,21]. A similar result was also reported by $\mathrm{Xu}$ et al, and Laura and Caraciolo[2,10]. The findings from our study was statistically significant at $\mathrm{P}<0.05$.

The incidence and prevalence obtained among those who have had blood transfusion as against those who have not also emphasizes the possible implication of blood transfusion in the transmission of the infection, especially if there is contamination. This study identifies the incidence to be statistically significant at $\mathrm{P}<0.05$. A report by Corcoran and Doyle,[3], observed that despite the fact that parvovirus B19 infection can be transmitted via contaminated blood products; there is presently no strict regulatory prerequisite governing B19 contamination of pooled plasma or blood products prior to products release.

The prevalence of B19 antibodies among housewives when considering the occupation of the pregnant women 
studied, may implicate household contact in the transmission of the in fection. Previous studies reported that, the infection is commonly passed through respiratory tract secretions from close personal contact[2]. Statistically, there was no significant difference between B19 incidence and occupation during pregnancy but there was significant difference between B19 prevalence and occupation. A report of no significant differences found in maternal infection from occupational exposures was reported by Harger et al[22], and Valeur et al[23].

The high incidence and prevalence of infection with B19 virus among the pregnant women and the known dangers posed in pregnancy raise transfusion policy questions in Nigeria. Like other blood-transmissible viral infections, routine screening for B19 virus infection before transfusion should, as a matter of policy, be made compulsory in Nigeria.

\section{Conflict of Interest}

There is no any conflict of interest.

\section{ACKNOWLEDGEMENTS}

Our special regards to the ethical committee members of Federal Medical Center, Keffi, Dr Simon Agwale, the Director of Innovative Biotech Virology Laboratory Keffi, for his support and cooperation during this research.

\section{REFERENCES}

[1] American Academy of Pediatrics Committee on infectious Diseases (1990). Parvovirus, Erythema infectiosum, and pregnancy. Pediatrics, 85:131.

[2] Xu J, Raff TC, Muallem NS, Nenmert AG (2003) Hydrops fetals secondary to parvovirus B19 infection. Journal of America Board of family practice, 16:63-68.

[3] Corcoran A and Doyle S (2004) Advances in the biology, diagnosis and host-pathogen interactions of parvovirus B19. Journal of Medical Microbiology,53: 459-475.

[4] Miller E, Fairley CK, Cohen BJ, and Seng C (1998) Immediate and long term outcome of human parvovirus B19 infection in pregnancy. British Journal of Obstetrics and Gynaecology, 105: 174-178.

[5] Skjoldebrand-Sparre L, Tolfvenstam T, Papadogiannakis N, Wahren B, Broliden K, and Nyman M (2000) Parvovirus B19 infection: association with third-trimester intrauterine fetal death. British Journal of Obstetrics and Gynaecology,107: 476-480.

[6] Cossart YE, Field AM, Cant B and Widdows D (1975) Parvovirus-like particles in human sera. Lancet, 1: 72-73.

[7] Woolf AD and Cohen BJ (1995) Parvovirus B19 and chronic arthritis - causal or casual association. Annal of Rheumatoid
Diseases, 54: 535-536.

[8] Van Elsacker-Niele AM, Salimans MM, Weiand HT et al (1989) Fetal pathology in human parvovirus B19 infection. Britain Journal of Obstetrics and Gynaecology, 96: 768- 775.

[9] Morey AL, Ferguson DJ and Fleming KA (1993) Ultra structural features of fetal erythroid precursors infected with parvovirus B19 in vitro: evidence of cell death by apoptosis. Journal of Pathology, 169: 213-220.

[10] Laura ERiley, Caraciolo J Fernandes,(2008) The in ciden ce of human parvovirus B19 infection during pregnancy and its impact on perinatal outcome: Parvovirus B19 infection in fetal deaths. Clinical Infectious Diseases; 47:1519.

[11] Markenson GR, Yancey ML (1998). Parvovirus B19 infections in pregnancy. Seminar on perinatology, 22:309.

[12] Wegner CS and Jordan JA (2002). Human parvovirus B19 binds placental cytotrophoblast cells via globoside receptor. Poster presented at the IX Parvovirus Workshop, Bologna, Italy, 28-31 August 2002.

[13] os-Wikip edia (2009). The free ency clop edia. http://en. wikip edia.org/wiki/Jos

[14] Keikha F, Miri-Moghaddam E and Sharifi-Mood B (2006). Prevalence of parvovirus B19 infection in successful and unsuccessful pregnancy in Zahedan, south east of Iran. Journal of Medical Science, 6(3): 495-497.

[15] Kaur P and Basu S (2005). Transfussion-Trasmitted infections. Existing and emerging pathogens. Journal of Postgraduate Medicine; 51:146-151

[16] Eis-Hübinger AM, Dieck D, Schild R, Hansmann M and Schneweis KE (1998). Pavorius B19 infection in pregnancy. Intervirology, 41:178-184.

[17] Mossong JN, Hens V, Frienderich I, Davidkin M, Broman B, Litwinska J, Siennicka A, Trzeinska PV, Damme P, Bentel A, Vyse Z, Shkedy M, Aerts M, Massari and Gabitti G (2007). Parvovirus B19 infection in five European Countries; seroepidemiology, force of infection and maternal risk of infection. Epidemiology of infection (E-Publish ahead of print).

[18] Letalef M, Vanham G, Boukef K, Yacoub S, Muylle L, Mertens G (1998). High prevalence of parvovirus B19 in Belgian as compared to Tunisian Blood donors: Differential implication for prevention of transfusional transmission. British Journal of Obstetrics and Gynaecology, 105: 174-178.

[19] Kerr S, O'Keeffe G, Kilty C, and Doyle S (1999). Undenatured parvovirus B19 antigens are essential for the accurate detection of parvovirus B19 IgG. Journal of Medical Virology,57: 179-185.

[20] Tuckerman JG, Brown T and Cohen BJ (1986). Erythema infectiosum in a village primary school: clinical and virological studies. Journal of Royal College of General Practitioners,36: 267-270.

[21] Grilli EA, Anderson AJ, and Hoskins TW (1989). Concurrent outbreaks of influenza and parvovirus B19 in a boys' boarding school. Epidemiology of Infection, 103: 359-369.

[22] Harger JH, Adler SP, Koch WC, and Harger GF (1998). Prospective evaluation of 618 pregnant women exposed to parvovirus B19: risk and symptoms. Obstetrics and 
Gynecology, 91: 413-420.

[23] Valeur-Jensen AK, Pedersen CB, Westergaard T, Jensen IP, Lebech M, Andersen PK, Aaby P, Pedersen BN and Melbye M (1999). Risk factors for parvovirus B19 infection in pregnancy. Journal of American Medical Association;281: 1099-1105.
[24] Enders M, Schalasta G, Baisch C, Weidner A, Pukkila L, Kaikkonen L, Lankinen H, Hedman L, Söderlund-Venermo M, Hedman K (2006). Humanparvovirus B19

[25] infection during pregnancy-value of modern molecular and serological diagnostics.Journal of Clinical Virology; 35(4):400-6. 